\title{
ON A NEW MEDUSA, AMPHINEMA KRAMPI N.SP.
}

\author{
By F. S. Russell, F.R.S. \\ The Plymouth Laboratory
}

\section{(Text-figs. I and 2)}

In a collection of plankton made by R.V. Sarsia, in a $2 \mathrm{~m}$ stramin ring trawl at $47^{\circ}$ I2 $2^{\prime} \mathrm{N} ., 7^{\circ} 40^{\prime} \mathrm{W}$., on $2 \mathrm{I}$ July I955 with 450 fathoms of wire out, there was a small anthomedusa which does not agree with any previously described species.
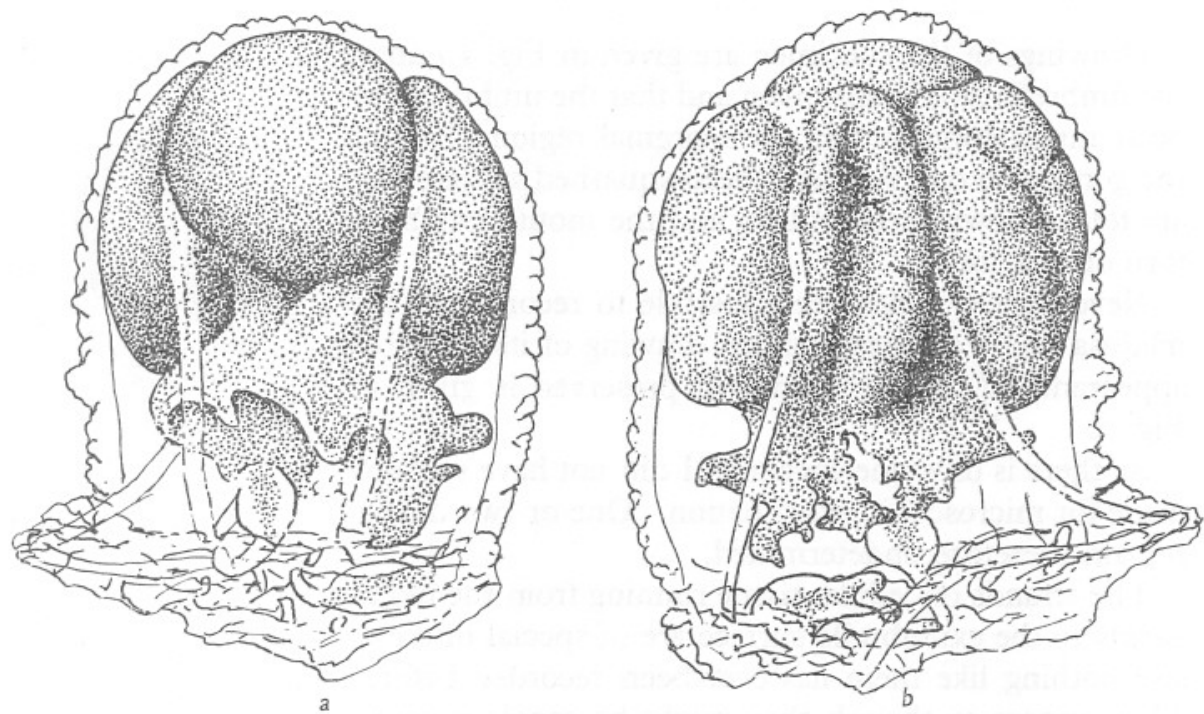

Fig. I $a, b$. Amphinema krampi n.sp.; the specimen has been drawn from both sides to show it as it actually looks in the preserved state.

The specimen is sufficiently well preserved to show its chief characters, and apparently belongs to the family Pandeidae. Its characters are such that it can be included in the genus Amphinema.

I have great pleasure in naming the medusa Amphinema krampi n.sp. in honour of P. L. Kramp, the world's leading authority on medusae.

\section{Amphinema krampi n.sp.}

The umbrella is bell shaped and higher than wide; the jelly is much wrinkled and contracted but would in nature have been fairly thick; there is no apical process. The stomach is cross-like in section and about two thirds the length 
of the subumbrellar cavity; it has no peduncle. The mouth is cruciform with four simple lips with a thickened margin and almost no crenulation. The four radial canals and ring canal are fairly broad; they have smooth margins; there are about twelve strands of cellular tissue running from each radial canal to the exumbrella surface, distributed along the length of each canal between the summit of the stomach and the level of the mouth lips. The gonads, which are male, form four simple cushions, one on each interradial surface of the stomach. There are two opposite perradial marginal tentacles with swollen elongated basal bulbs, and eight marginal tentaculae. There are no ocelli. The height of the umbrella is about $6 \mathrm{~mm}$ and it is about $4 \mathrm{~mm}$ wide. The colour of the stomach and gonads is rich reddish brown, and there is a core of brownish pigment in the ring canal extending into each of the two marginal tentacle basal bulbs; the marginal tentaculae are colourless.

Drawings of the specimen are given in Fig. I $a$ and $b$. It can be seen that the umbrella jelly is shrunken and that the umbrella has been much contorted in the marginal region. Two of the gonads on one side have been squashed so that they are folded down their centres, and the mouth has been torn on that side.

Nevertheless it has been possible to reconstruct the medusa fairly accurately and a drawing of its probable appearance if it had been well preserved is given in Fig. 2.

As there is only one specimen I did not have sections made for microscopic examination. One or two details remain therefore undetermined.

The strands of cellular tissue running from the radial canals to the exumbrella surface are of special interest, and nothing like them has ever been recorded before. They appear as though they might be canals running from the radial canals to the exterior, but microscopic sections would be required to prove whether this

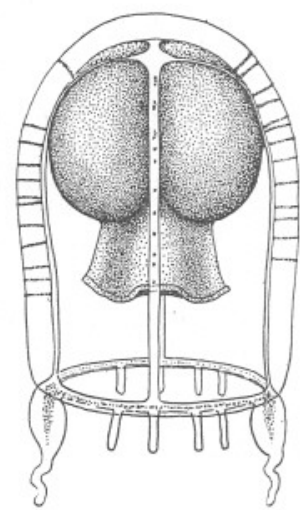

Fig. 2.

Amphinemakrampin.sp.: the medusa reconstructed as it would probably appear if well preserved. were so.

The marginal tentacles appear to be typical of pandeid medusae and it is probable that they are hollow. The marginal tentaculae are uniformly covered with nematocysts. The distribution of the tentaculae around the margin of the umbrella is rather irregular. In one sector at any rate, one tentacula is perradial so that there are two in one interradius and one in the other. The distribution appears to be similar in the other sector, but as the radial canal is damaged on that side it is not possible to say for certain whether one tentacula is perradial. There is no indication that there are any missing tentaculae. 
Owing to the dark coloration it was not possible to tell the sex except by breaking one of the gonads, when the specimen was found to be a male.

The following characters distinguish Amphinema krampi from other species in the genus: no apical process; cellular strands of tissue running from radial canals to exumbrella surface; four simple interradial gonads.

The specimen has been deposited in the British Museum (Natural History) and has been given the registered number B.M. I956.I.IO.I.

My thanks are due to Captain C. A. Hoodless and the crew of R.V. Sarsia, who made the collection in which the specimen was found.

\section{SUMMARY}

A single specimen of a new pandeid medusa was caught in deep water off the mouth of the English Channel in July 1955.

A description is given, and the species has been named Amphinema krampi n.sp. 